\title{
明治宮殿の設計内容に見る御学問所の用途と意匠的特徵 THE USES AND THE CHARACTERISTICS IN THE DESIGN MEANINGS OF THE MEIJI PALACE'S OGAKUMON-JO
}

\author{
山崎 鯛 介* \\ Taisuke YAMAZAKI
}

\begin{abstract}
This paper shows that the Ogakumon-jo (literally the Emperor's studying room) in the Meiji Palace was designed in relation to the Emperor's works (mainly the affairs of state, studying, dinning with his cabinet, etc). In the history of this project; the Ogakumon-jo was generally designed as twostoried building because it was needed to separate the space for each exclusive use of his works, and it was also needed to combine them as one building for the formality following the Kyoto Palace's building arragement. These exclusive uses were also expressed on their interiors.
\end{abstract}

\footnotetext{
Keywords : the Meiji Palace, Ogakumon-jo, the Kyoto Palace, the Akasaka Temporary Palace, tradition, Modern Japanese-style 明治宮殿、御学問所、京都御所、赤坂仮皇居、伝統、近代和風
}

\section{1. 緒言}

明治 21 年に竣工した明治宮殿（正式には「皇居宮殿」）の意匠的特 徵について、筆者はこれまで4本の論文において、竣工建物に見られ る具体的な特徵とそれらの形成過程について論じてきた。そのうち先 行する3論文では、壮麗かつ和洋折東の内部空間で知られる表宮殿の 建物について、その意匠的特徵がどのような設計意図に基づくもので あるかを、主に建物の「用途」との関倸に注目しながら考察した。す なわち、「明治宮殿の建設経緯に見る表宮殿の設計経緯」1)では、明治 16年7月以降の実施過程における設計経緯を詳細に明らかにし、表宮 殿の特徵である大空間・和洋折衣の室内意匠が地鎮祭後に行われた 2 度の設計変更によって決められたこと、壁面や家具に用いられた洋風 意匠が洋風の宮中夜会を想定して導入されたと考えられること、そこ には宮内卿・伊藤博文の意向が反映している可能性が高いことなどを 明らかにした。続く「明治宮殿の設計内容に見る儀礼空間の意匠的特 徵」 2) では、竣工建物の室内意匠を表宮殿全体の平面計画とあわせて 考察し、表宮殿の平面計画が近代的な宮中儀礼に配慮して計画された こと、謁見所や㗽宴空間の室内意匠がそこで行われる宮中儀礼の内容 と関係づけてデザインされていたことなどを明らかにした。そして 「明治宮殿の造営過程に見る木造和風の表向き建物の系諧とその意匠 的特徵」3) では、造営過程において木造和風で計画された表向き建物
の系譜を明らかにし、そのうち明治14年の木造和風宮殿計画では「紫 宸殿」風の謁見所が計画され、明治 15 年の吹上宮殿計画では「小御 所」風の内謁見所が計画されるなど、伝統的な宮中儀式が行われる建 物の意匠には、「宮殿」としての格式を示すために京都御所風の意匠 が繰り返し用いられてきたことを明らかにした4)。

本研究では、これら先行論文では詳細に論じてこなかった「御学問 所」を取り上げ、建物の用途に注目しつつ、竣工建物の意匠的特徵と 設計経緯を明らかにする。建物の用途に注目する理由は、設計過程を 見る限り「御学問所」と称する建物には「学問」以外にも多様な用途 が想定されていたと考えられるからであり、例えば計画案には建物の 呼称を「御学問所」としながら 2 階に「会食所」を設けた例も見られ、 また部屋名を「御学問所」としながらも、明らかに天皇の日常の御座 所を意図したと考えられる例も見られる。明治以降の天皇に見られる 多様な日常的活動は、江戸時代以前には見られない「近代の天皇」に 特有の役割であり、そうした多様な活動を支える施設をどのように設 けるかも「近代の宮殿」にとって重要な課題であったと考えられる。 よって本研究では、考察の対象とする用途を「学問」に限定せず、日 常政務やその他の天皇の日常的な活動内容を広く含むこととする。

竣工建物の意匠的特徵としては、表宮殿の主要建物で唯一、木造二 階建てで建設されたことが知られている。本研究では、なぜ御学問所 
のタが木造二階建てで建設されたかついて、その理由を設計過程も含 め、先述した用途の多様性との関係から論じることを試みる。

既往研究では、明治宮殿の御学問所について、設計経緯も含めて用 途や意匠的特徵を詳細に検討したものは見られない。

ところで、「御学問所」の呼称を持つ建物は、江戸時代以前の禁裏 や公家の邸宅内にも建設されていたことが知られている。近世の御学 問所に関する研究には、藤岡通夫『京都御所 [新訂]』(中央公論美術 出版、1987 年) や平井聖「禁裹における学問所について」(『日本建 築学会論文報告集』第 60 号、pp.601-604、1958 年 10 月）があり、 中世から近世初頭にかけては、藤田勝也の 2 論文「中世天皇御所にお ける御学問所の成立と展開」(『日本建築学会計画系論文集』第560号、 pp.269-276、2002 年 10月）と「中近世天皇御所における御学問所 の変容と展開」（同前、第 580 号、pp.221-227、2004 年 6 月）があ る。ここでは「御学問所」の用途について、江戸時代以前には「学問」 以外に対面の場としても使われていたこと5)、またそうした学問や対 面においても儀礼的な性質は少なく、天皇の私的空間としての性質が 強く見られること6) などが指摘されている。このような「御学問所」 の性質が、明治宮殿の御学問所にどのような形で継承されているかは 興味深いテーマであり、本研究でもそうした点を念頭に置いて、計画 案の用途や意匠的特徽を京都御所の御学問所と適宜比較した。

なお、明治宮殿の御学問所についで論じる前に、第 2 章では赤坂仮 皇居における天皇の日常的な活動と、そこで用いられた建物の特徽に ついて論じる。赤坂仮皇居が使用された明治初期には「近代の天皇」 としての役割はまだ明確ではなく、仮皇居における天皇の行動形式も 多分に過渡的な状態であったと考えられる。よって明治 12 年以降の 皇居造営計画については、同時期の赤坂仮皇居におけるこうした過渡 的な状態を前提に比較・考察することが必要と考えられる。

史料には、赤坂仮皇居については『明治天皇紀』7) と宮内庁所藏『工 事録』（内匠寮）を主に用い、明治宮殿については『皇居造営録』(皇 居御造営事務局、明治 9 年 23 年) と『皇居御造営誌』、『皇居御造 営内部諸装飾明細図』(いずれも内匠尞、明治 25 年)、そして東京都 立中央図書館木子文庫所収の明治宮殿関係史料をあわせて検討した。 なお、建物の呼称は宮内省から明治 21 年 12 月 27 日に布達が出され、 計画案で「御学問所」とされていた部屋は「表御座所」へと改称され たが、本研究では設計経緯を扱う関係上、造営中の呼称を用いる。
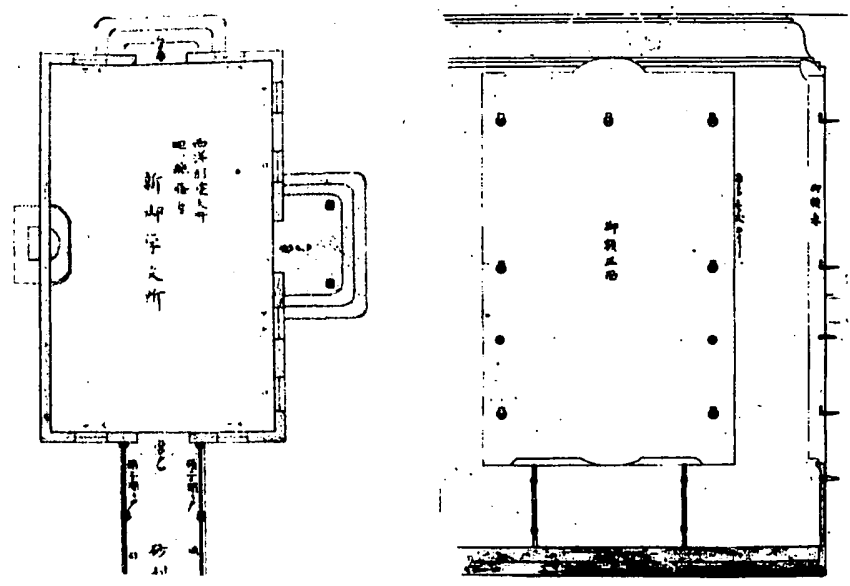

図 1 （左）.赤坂仮皇居新築御学同所平面图（宮内庁所藏、明治 13 年頃、部分） ※上方が南

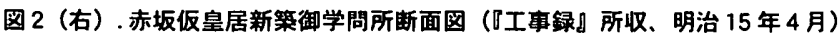

\section{2. 赤坂仮皇居における天皇の日常的な活動とそのための施設}

西ノ丸皇居が明治 6 年 5 月に焼失したのに伴い、赤坂離宮には「仮 皇居」が設置され、その施設として旧紀州徳川家中屋敷の建物が転用 された。そこでは近代的な「仮皇居」としての体裁を整えるため、既 存建物の改修や増築が行われたと考えられるが、本章では、このうち 御座所や御学問所など天皇の日常的な活動に用いられた建物について 工事の内容を『工事録』から明らかにし、『明治天皇紀』からわかる 活動内容と併せて検討することで、仅皇居における天皇の行動形式と 建物の空間特性がどのように関係づけられていたかにういて論じる。 赤坂仮皇居に新築された建物としては、明治 7 年 12 月頃に「素朴 なる木造西洋式建築」 ${ }^{8)}$ として建設された洋風の御学問所がある。宮 内庁所藏「赤坂仮皇居御座敷向之図」(図 1) ${ }^{9)}$ から、建物は平面が招 よそ 30 帖（5間 $\times 3$ 間） ${ }^{10 ）}$ の 1 室空間で、内部仕上は「西洋形塗天 井名リ総張付」であったことが知られる。また『工事録』所収の断面 図（図2） ${ }^{11)}$ から、天井高は約 15 尺と高かったことがわかる。「西洋 式」の要素としては、断面図に描かれた天井のモールティングや高さ 約7.5寸の巾木のほか、室内に据えられた暖炉や床仕上げの䄉毯敷き

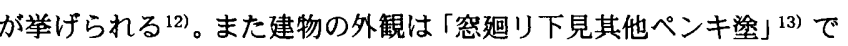
あったと『工事録』に記されている。

新築の理由について『明治天皇紀』には、以下のように移転当初に は「御学問所代」と称する場所で日常政務と「御講学」の両方が行わ れていたものの、それが御講学に不都合であったため、新たに御講学 専用の建物として、この「御学問所」を建設したと記されている。

「赤坂假皇居は其の規模狭小にして、特に御講学のために用るたまふへへき宮室 なし、習字のみは梅間（隩・壁張等に畦梅を画ける階下の一小室なり）を用る たまへども、其の他は御学問所代に於て学習したまふを常とす、御学問所代は 階下の二室にして、各室二十帖を敖くべし、然れども日常政務を執らせたまふ 所なるを以て、御講学に便ならず、是を以て舞に御学問所代西南方の地をトし て新に御学問所の建設に著手し、既にして成る」（明治 7 年 12 月 22 日条） また、室内には天皇の御講学の相手をする宮内省九等出仕 4 人分の机 も置かれていたことが、以下の記述からわかる。

「其の中央西寄りに東面して玉座を設け、傾斜面の西洋式机を置く、玉座の左 右に各々二脚の机を並べて御相手奉仕の宮内省儿等出仕藤波言忠・同大原重 朝・同堤亀穈・同获昌吉等の席と為す、請師の座位は東寄り梢々北方に土座に 面して之れを設け、平面の机一脚を置く」（明治 7 年 12 月 22 日条）

以上のことから、御学問所が 1 室大空間の建物として新築された理 由は、建物の用途である御講学が、天皇と数人の宮内省九等出仕が一 緒に行う形式で行われ、それを可能にする建物が必要とされたためと 考えられる。そして、建物を洋風意匠とした理由には、御講学の科目 にドイツ語をはじめ、西洋的な科目が多く選択されていたことが関係 していると考えられる14)。

改修された場所では、御座所の 2 階が注目される。天皇の御座所は、 後に日光田母沢御用邸に移築された 3 階建ての建物の1階部分に置か れていた ${ }^{15)}$ が、この 2 階部分について、明治 8 年 5 月〜 12 月頃に作 成されたと考えられる宮内庁所藏哧坂仮皇居切絵図敷物間地』 ${ }^{16)}$ (以 下『敷物間地』、図 3）を見ると、江戸末期には 2 室であった座敷 ${ }^{17)}$ が1室として描かれている。この部屋の改修記録を『工事録』に探す と、「表二階欄間取解天井張替其他営繥」（明治 7 年 2 月 5 日）がそれ に相当すると考えられ、文面から見る限り、部屋境の欄間を撤去し、 天井をフラットな紙貼天井に改修したものと見られる ${ }^{18)}$ 。工事録』に は、他にも「御学問所二階硝子障子建入其他営繥」(明治 9 年 11 月 26 日）や「表御二階用絨掞買上」（明治 11 年 12 月 18 日）といった記録 
があることから、改修後の御座所 2 階は、フラットな紙貼天井とガラ ス障子を備え、床に絨毯を敷いた 1 室空間であったと考えられる。

この 1 室空間に改修された御座所 2 階の用途については、『明治天

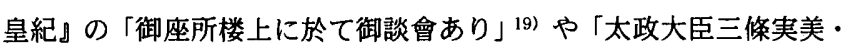
左大臣島津久光 - 右大臣岩倉具視・宮内卿德大寺実則 - 宮内大輔萬里 小路博房・侍従長東久世通礼を召し、御学問所代楼上に於て午餐に陪

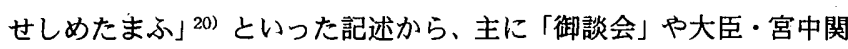
係者との御昼餐などに使用されたと考えられる。この「御談会」は、 以下の記述から明治 7 年 2 月の改修後すぐに始められたと考えられ、 また御昼餐に関する『明治天皇紀』の記事も、初出はほぼ同時期の明 治 7 年 4 月 30 日となっている。

「御談會は君臣談論を交ふるの御會なり(中略)其の始めて開催せられたるは、 蓋し六年の終より七年の初に在り、(中略) 而して侍坐する者、時に大臣・参 議等の参候することありと雖も、大抵宮内卿・侍従長・侍読の臣及び従四位留 藤利行・宮内省御用猢皇山義成等五六人なり」(明治 7 年 5 月 17 日条)

以上のことから、移転後まもない明治 7 年 2 月に御座所の 2 階を 1 室空間へと改修した目的は、皇と臣下との親睦を深める場を設ける ためであったと考えられる。御座所の 2 階が選ばれた理由としては、 それが公式の宮中儀礼が行われる1階の「小御所代」や「旧御学問所」、 また政務を執る「御座所」などと空間的に離れている上、眺望も良く やや内向きのくつろげる空間であったためと考えられる。

ところで、こうした御講学や宮中関係者との御昼餐は、明治 13 年 以降に天皇の政務が多忙になってくると、次第に行われなくなって 行ったと考えられる。すなわち、天皇の内閣への臨御は明治 10 年 9 月 2 日に正式決定され、明治 13 年 3 月 18 日には日曜・祭日を除く毎日 の朝 10 時から内閣に臨御するように定められたが21)、『明治天皇紀』 を見ると、この明治 13 年を境に御講学と御談会の回数が急速に減少 している ${ }^{22)}$ 。使い方の変化は、御座所 2 階にも見ることができ、当初 は大臣や宮中関係者を対象とした御談会や御昼餐が行われていたのに 対し、明治 10 年 10 月以降になると、内閣との関係をより重視した「御 陪食」が行われるようになる。『明治天皇紀』の記述を以下に示す。

「是れより先侍補相談して日く、大臣・参議が議政上の洋謁は日々内閣に於て 行はるべし、然れども水魚の親しみ未だ深からず、君臣上下の親和を図らんこ と御陪食の制を設けらる〉に若くは無しと、乃ち数々太政大臣・右大臣に忿㴓 する所あり、閣議遂に之れに同意し、閣臣一人・當番侍補二人に時々御陪食仰 付けらる〉ことと定む、然るに侍補は、閣臣一人にては其の効力なしとて抗拒 する所あり、仍りて更に大臣・参議各一人、當番侍補二人と定め、以て部虑を 候す、天皇之れを裁可し、是の日其の第一回を行ひたまへるなり、爾後、毎週 金曜日を以て其の日と定めらる」(明治 10 年 10 月 27 日条)

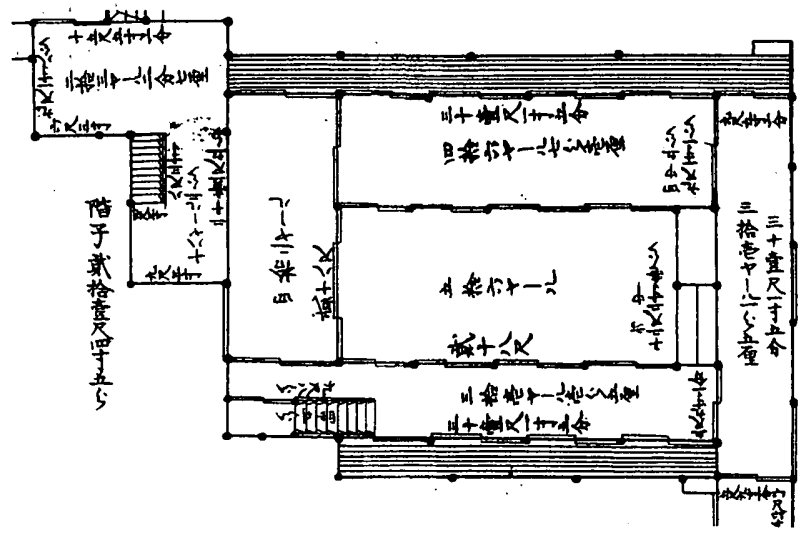

図 3. 赤坂仮皇居御坐所 2 階平面図（宮内庁所藏『数物間地』上り、部分） 明治 8 年 5 月 12 月比、上方が南
この「御陪食」は、内閣臨御の日が改定された明治 13 年 3 月以降 に「三月以降陪食者の範囲を拡張して、諸省卿輔、議官以上の元老院 官吏及び陸海軍武官をも召したまふ、又臨期に規定外の勅任官及び海 外派出公使等を召さる〉こととす」 ${ }^{23)}$ と、陪食者が大幅に增員されて いることから、天皇と内閣の関係を強化する制度としてこの時期に新 たに導入されたものの一つであったと考えられる24。

以上のように、この時期の天皇の日常的な活動としては、御座所で の日常政務以外にも、御講学や御談会・御陪食などがあった。移転後 の赤坂仮皇居で行われた改修・增築工事は、これら天皇の多様化した 活動内容のそれぞれに対し、個別の場を与えることを目的に行われた ものであったと考えられ、具体的には明治7年に洋風の御学問所が御 講学専用の施設として新築され、1室空間に改修された御座所の 2 階 では「君臣親和」のための御談会や御陪食が行われた。なお、御学問 所が洋風意匠で新築された理由は、御講学の内容が西洋的なものを重 視していたことに因んだためと考えられ、これは御学問所の意匠を用 途と関係づけて決めた初期の事例として見ることができる。

\section{3. 吹上宮殿における2 階「会食所」の設置と御所風の外観意匠}

竣工した明治宮殿の御学問所が表宮殿の他の建物と比べて大きく異 なる特徵の一つに、木造 2 階建てである点が挙げられる。なぜ 2 階建 てであるかについては、それが山里と西/丸の境界という高低差のあ る場所に建てられたためとも考えられるが、宮内庁所蔵『皇居御造営 誌編纂下調図』(以下『下調図』) 所収の計画案を見ると、2 階建ての 計画案は平地に計画された吹上宮殿において既に登場しており、よっ て2階建てはそうした敷地形状の特性からではなく、建物に想定され た用途との関係から選択された可能性の方が高いと見られる。吹上宮 殿の御学問所が2階建てで計画されるようになったのは、『下調図』に おいて初めて階段が描かれた明治 14 年 9 月 12 日案（第 32 号）から と考えられ、その後は「吹上最終案」(明治 15 年 12 月 27 日案 : 第 66 号) まで、一貫して2階建てで計画されている。よって吹上宮殿では、 事業組織である「皇居造営事務局」が設置された明治 15 年 5 月 27 日 以降のすべての計画案が 2 階建てで計画されたと見てよい。このうち 明治 15 年 10 月 4 日案（第 57 号）については、木子文庫に同時期の ものと考えられる $1 \cdot 2$ 階の平面図 ${ }^{25)}$ や矩計図 ${ }^{26)}$ 、立面図 (妻側・平

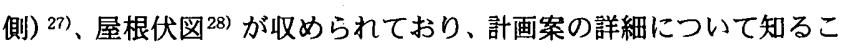
とができる。そこで本章では、まずこの 10 月案の設計内容について 詳細に明らかにし、それを前章で明らかにした当時の天皇の行動形式 と併せて考察することで、吹上宮殿の御学問所にはどのような用途が 想定され、またなぜ 2 階建てで計画されたかについて論じる。

まず、1 階の平面（図 4 上）について見ると、部屋を 6 間取りとし て四周に入側を設け、一之間である「御学問所」(12.5帖)の床・棚 を庭と反対側の壁面に設けた点は、京都御所の御学問所と同じ形式と いえる。これと似た形式の空間を赤坂仮皇居に探すと、喿・棚を備え た主室と次の間・入側からなる平面形式という点では「御座所」の平 面が共通している。また矩計図を見ると、1階部分の巭仕上げは入側 部分が厚板張りであるのに対し、「御学問所」室内は畳敷きのように 描かれている29)。床仕上げについては、赤坂仮皇居の御座所もまた聖 德記念絵画館壁画「侍講進講」や「兌換制度御治定」において、床仕 上げが畳の上に䄉毯を敷いたように描かれており ${ }^{30}$ 、両者の床仕上げ は同じ形式で計画されていたことも考えられる。 
また、この他に 1 階平面で両者が共通している点としては、建物に 隣接して「呉服之間」が設けられた点が挙げられる。吹上宮殿の計画 案では『下調図』を見る限り、明治 15 年 6 月案 ${ }^{31)}$ 以降のすべての案 において「呉服之間」が計画されたと見られるが、赤坂仮皇居でもこ の「呉服之間」は御座所に隣接して設けられている。この部屋の用途 を示した記録はないが、同様の部屋が京都御所には見られないこと、 計画案では常に御座所よりも広い面積で計画されたことなどから見 て、宮中儀式の際の衣装直しの場 ${ }^{32)}$ として計画されたことが考えら れる。このように、吹上宮殿の 1 階には赤坂仮皇居の御座所と共通の 形式が多く見られることから、「御学問所」と記された床・棚付きの 部屋は、天皇の日常的な御座所として計画された可能性が高い。

2 階には、平面図（図4下）に見られるように、大面積の「会食所」 (4間 $\times 7$ 間 $=56$ 帖）が計画された。部屋の用途である「会食」につい ては、規模が 56 帖と三大節賜宴 ${ }^{33)}$ を行うには狭く、また 2 階の 1 室 空間という点が赤坂仮皇居の御座所 2 階と共通していることから、御 陪食などが想定されたと考えられる。矩計図を見ると、会食所の巭は 入側・室内ともに厚板張りで設計され、また内法高も 2 階は 6.6 尺と、 1階の6.54尺 (敷居天端〜無目下端)よりも若干高く設定されるなど、 立式を前提にした工夫は 1 階「御学問所」よりも明確に見られる。一 方で、建物の呼称が!御学問所」であるにも関わらず、平面計画では 「御講学」のための空間が確保されていない。宮殿全体で見ても、他
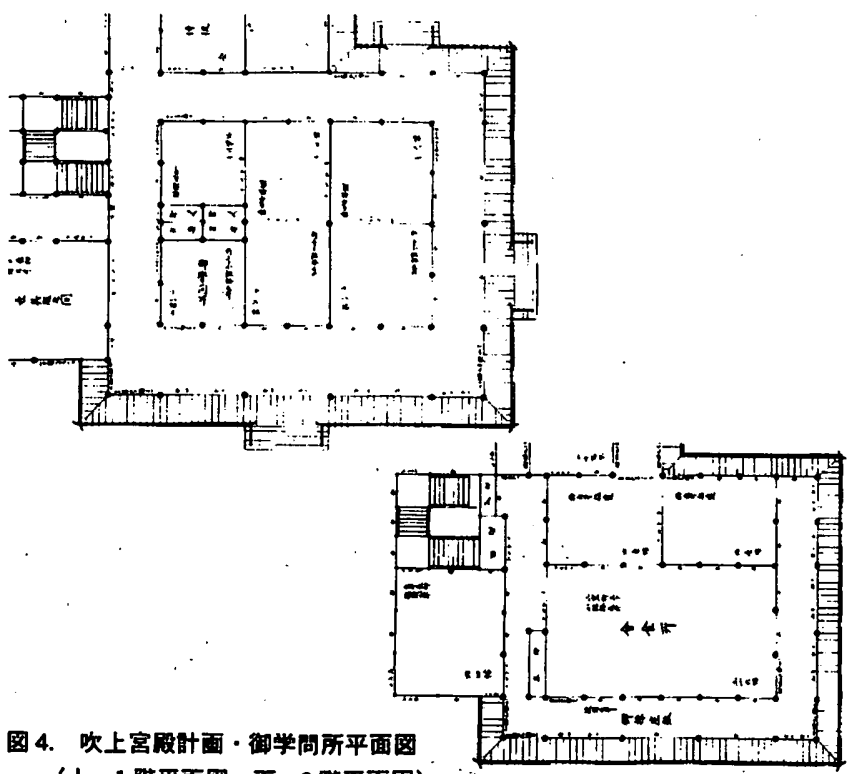

图 4. 吹上宮殿旪面・御学问所平面图 （上：1.陵平面图、下:2 階平面图） （木子文庫所藏・部分、明治 15 年 10 月頃）いずれも上方が北

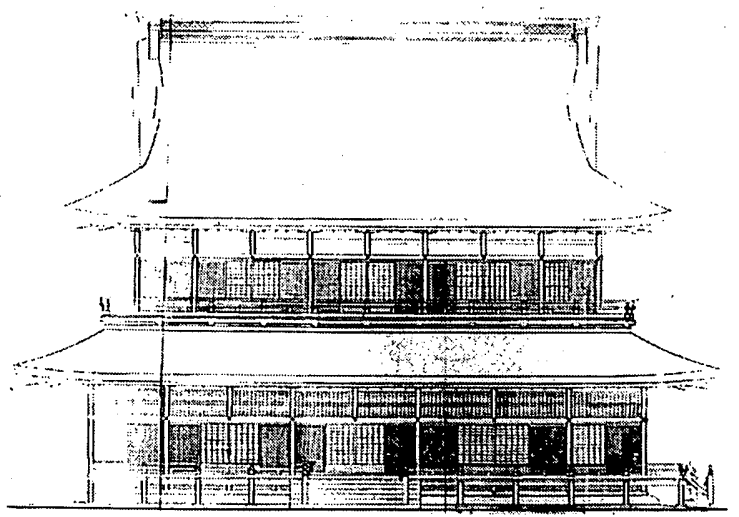

图 5. 吹上宮殿計画・御学問所南立面図（宮内庁所葴、日付なし）
に御講学専用の建物が計画された様子は見られないがここれは前章で 述べたように、明治13年以降、天皇の御講学があまり行われなくなつ たことが影響していると考えられる。

建物の意匠に関しては、赤坂仮皇居との共通点はあまり見られず、 むしろ 2 階建てであることを除けば、京都御所の御学問所との共通点 が比較的多く見られる。具体的には、1 階「御学問所」と2階「会食 所」の天井意匠に素木の (二重) 折上小組格天井が用いられたほか、 入側建具に舞良戸と障子、外周建具に「タテ蔀戸」と明障子を用いた 点、さらに立面図（図5）から、橡に勾欄を設け、外周部の小壁に錐 形付きの木格子欄間 ${ }^{34)}$ を設けた点が御所の御学問所との共通点とし て指摘できる。また、屋根伏図に「銅茵」と記された屋根や庇は、立 面図を見る限り平真きで計画されたと考えられ、御所の懀皮莫きを意 識した可能性も考えられる。立面のプロポーションも、1.階部分につ いては御所とほぼ同じと見てよく、計画案では建物の幅 (平側) が 11 間と京都御所の 9.5 間よりやや大きいが、内法高（無目下端）も京都 御所の 6.1 尺 $^{35)}$ よりもやや高い 6.5 尺で計画され、全体のバランスは 維持されたと見て良い。なお、計画案には同時期の聖上常御殿 ${ }^{36)}$ に 既に導入されていたガラス障子や暖炉が見られないが、これも立面に 煙突やガラス障子が現れることを避けたためと見ることもできる。

以上のように、吹上宮殿の御学問所では 1 階が御座所、2 階が御陪 食の場として計画されだと考えられる。これを前章で見た赤坂仮皇居 と比較すると、両者の共通点としては、天皇の多様な活動内容のそれ

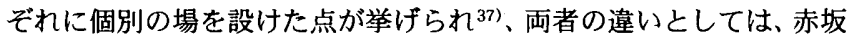
仮皇居ではそれを個別の建物を複数建設することで対応したのに対 し、吹上宮殿では 2 階建ての建物 1 棟に絔めることで対応した点が挙 げられる。吹上宮殿の御学問所が 2 階建てで建設された理由は、異な る用途ごとに部屋を設けつつも、「宮殿」を構成する建物としては京 都御所と同様に「御学問所」と称する建物 1 棟に總めることが必要と 判断されたためと考えられ、そうした御所に倣う姿勢は、建物の意匠 に御所風が多く適用された点にも窥える。拙稿 ${ }^{38)}$ で論じたように、吹 上宮殿では隣接する内謁見所においても室内に99帖の大空間を確保 しつつ、「宮殿」としての格の高さを示すために京都御所の「小御所」 とよく似た意匠が適用されたが、こうした御所風の意匠を適用する姿 勢は、吹上宮殿の基本的な設計態度であったと考えられる。

\section{4. 実施過程における 1 階「広間」の拡大と 2 階「御学問所」の設置}

山里正殿・吹上宮殿計画はその後中止され、明治 16 年 7 月には再 び敷地を西ノ丸と山里に移して「木製假皇居」計画（以下「実施過程」） が策定された。拙稿「明治宮殿の建設経緯に見る表宮殿の設計経緯」 （先掲）で論じたように、その後の設計過程では主に儀礼空間を対象 に、室内を壮麗化するための設計変更が加えられ、明治 17 年 4 月の 地鎮祭後には着工延期の期間に主要建物の天井高が払大され、躯体工 事が一段落した明治 20 年には室内意匠が大幅に洋風化された。御学 問所と内謁見所は、ともにこうした壮麗化の対象から外れていたが、 史料の日付から、御学問所もほぼ同時期に設計変更が加えられていた ことが知られる。まず本章では、木工事着手までの設計過程について 詳細に検討し、主として平面計画の分析から、建物に想定された用途 がどのようなものであったかについて考察する。そして、その内容を 前章で見た吹上宮殿の計画案と比較することで、両者の間にどのよう な違いが見られるかについても明らかにする。 


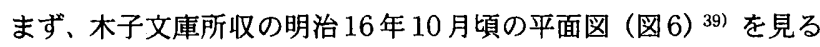
と、実施過程の当初、御学問所は平屋建てで計画され、同時に内謁見 所の東側に 2 階建ての「休敗之間」が計画されたことが知られる。こ の「休䄭之間」は、吹上宮殿では御学問所 2 階に設けられていた「会 食所」を独立させたものと見ることができ、建物を独立させた意図と しては、御学問所や内謁見所だけでなく、「休䕀之間」を新たに木造 で計画された会食所とも関係づけようとしたためと考えられる。それ は、この建物の呼称がその後の設計過程で「休螅之間」からやがて「後 席之間」に変更 ${ }^{40)}$ され、竣工後には後席之間の小食所（竹之間）に

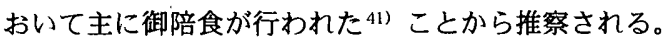

一方、平屋建てで計画された御学問所については、平面が6間取り で四周に入側を迴し、外周建具に「タテシトミ戸」を用いた点が吹上 宮殿の1階平面と共通している。その他の吹上宮殿との共通点として は、同時期と考えられる矩計図 ${ }^{42)}$ において、室内の床仕上げが「畳」 で計画されたことや、同様に平屋建てで計画された明治 17 年 1 月頃 の計画案の起こし絵図（図7） ${ }^{43)}$ において、外周欗間に鉄形付きの木 格子欄間が用いられた点などが挙げられる。よって平屋建ての計画案 には、吹上宮殿の 1 階部分の形式がほぼ踏襲されたと見て良い。

御学問所は、表宮殿の床面積が倍增された後の明治 17 年 2 月になつ て、再び2 階建てに変更された44)。その後も計画は2 階建てのまま設 計が進められ、明治 18 年 8 月には木工事仕様書である「御学問所築 造仕法書」（以下「仕法書」）が作成され、同年 10 月 7 日には木工事 に着手 ${ }^{45)}$ している。これら実施過程の計画案を見ると、吹上宮殿の 計画案と同じ2階建てではあるが、その平面計画は大きく異なってお り、両者では建物の用途に対する考え方が異なっていたと考えられ る。まず、木子文庫所収史料を用いて1階部分の平面形式を検討する と、明治 17 年 2 月 14 日案 ${ }^{46)}$ 以降のすべての計画案で、南列の部屋 は一之間と広間からなる 2 室構成で計画されている。このうち明治 17 年 5 月 7 日案（図 8 左） 47 ) と明治 18 年 1 月 28 日案（図 9 左） ${ }^{48}$ )を より詳しく比較すると、後者では床飾りの位置が北面から西面へと変

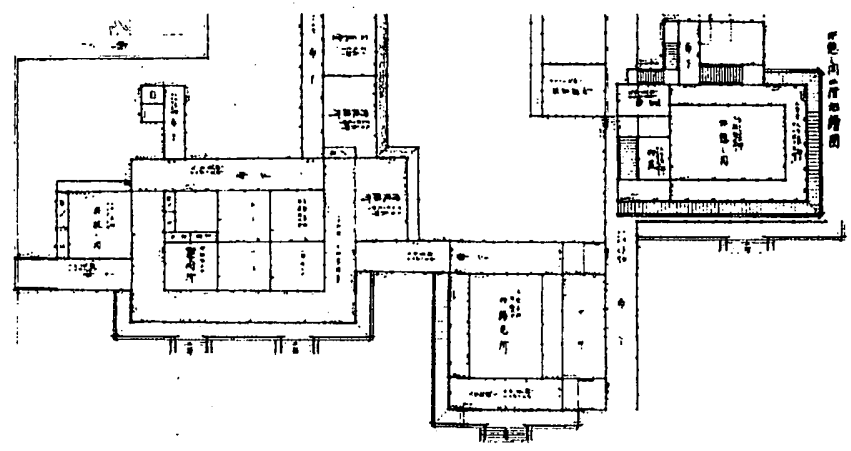

図 6. 明治 16 年 10 月頃の御学問所ほか平面図（木子文庫所収・部分）

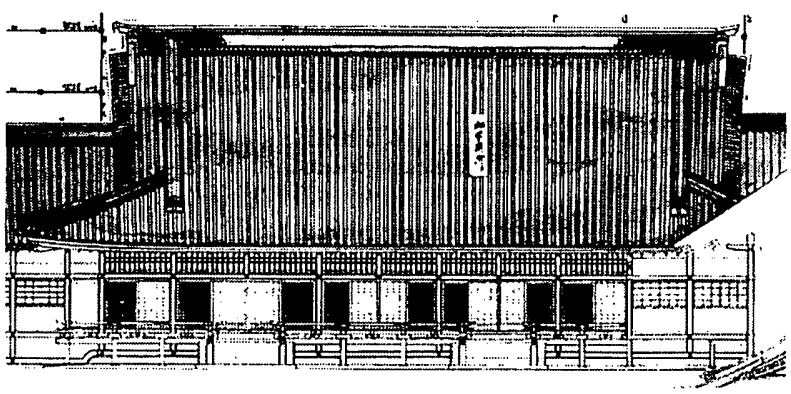

図 7. 明治 17 年 1 月頃の御学問所の起こし絵図（木子文庫所収・部分）
更され、前者では部屋境に設けられていた暧炉が西面の床脇へと移動 されたことがわかる。こうした変更は、通常は御座所として使う一之 間の規模を変えずに、建具を取り外すことで大面積を必要とする用途 にも对応できるようにしたエ夫と考えられ ${ }^{49}$ ）、休飾りの位置変更はそ うした場合を想定したものであったと考えられる。こうした大部屋と して使うことを想定した工夫は、高さ方向の寸法が若干拡大された点 にも見ることができ、明治 17 年 5 月頃に作成されたと見られる矩計 図 ${ }^{50)}$ と明治 18 年9月 13 日作成の矩計図 ${ }^{51)}$ を比較すると、階高は 22.05 尺から 22.59 尺へ、内法高（敷居天端～無目下端）は6.8 尺から 7 尺 へ、そして天井高（敖居天端～折上格天井の格縁下端）は 14.36 尺か ら14.65 尺へと、それぞれ高くなっていることがわかる。

2 階の平面形式については、明治 17 年 5 月 7 日案（図8右）と明治 18 年 1 月 28 日案（図9右）を比較したところ、いずれにも「御学問 所」と記された床・棚を持つ 20 帖程度の部屋が計画された点が共通 点として挙げられる。両者では間取りや部屋の形状が異なるが、これ は主に 1 階の暖炉・煙突位置の変更によるものと考えられる。2階の 平面形式には1階のように隣室と一体で使おうとする工夫は特に見ら れず、高さ方向についても、2 階の内法高・天井高にはほどんど変化 が見られない。この「御学問所」と記された一之間の用途としては、 将来的に必要とされる御講学の場が他に計画されていないことから、 文字通り御講学の場として計画された可能性が高いと考えられる ${ }^{52) 。}$

なお、前章で見たように、吹上宮殿の外観意匠には御所風の意匠が 用いられたが、実施過程の計画案にはそうした傾向が見られない。す なわち、明治 17 年 5 月 7 日案以降の計画案では、外周建具にガラス 障子が用いられるようになり、また明治 18 年 8 月作成の「仕法書」で は、 2 階の外周建具について「同所（筆者註 : 2 階）外側雨戸建戸袋 付」と、表宮殷の主要建物では唯一、雨戸形式が導入されたことが記 されている。この雨戸形式とカララス障子の導入により、建物の外観は 御所風の吹上宮殿と決定的に異なるものになったと考えられる。

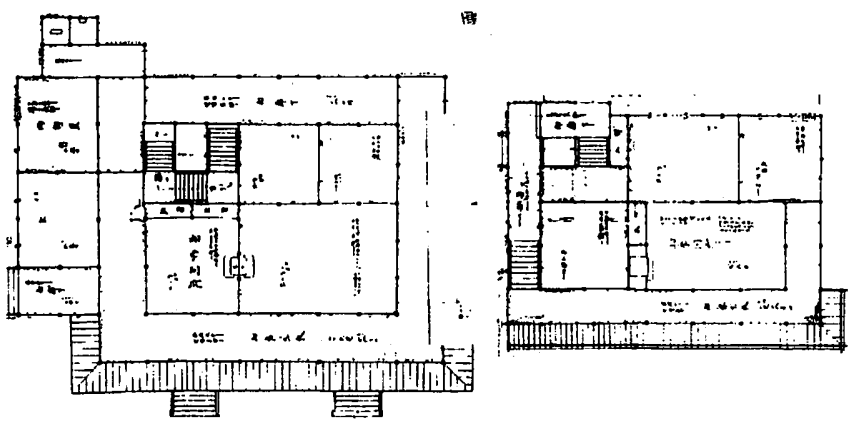

图 8. 御学問所 $1 \cdot 2$ 階平面図（明治 17 年 5 月 7 日、木子文庫所収・部分）
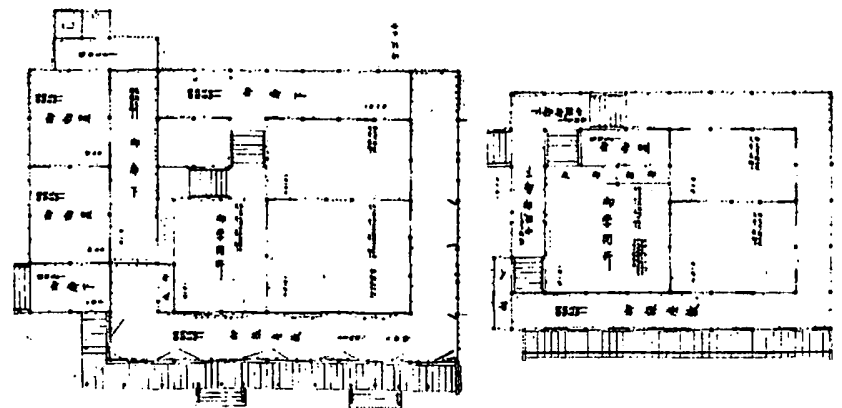

图 9. 御学問所 $1 \cdot 2$ 階平面图（明治 18 年 1 月 28 日、木子文庫所収・部分） 


\section{5. 竣工建物の室内意匠に見られる特徽とその意図}

竣工した御学問所の室内意匠については、『皇居御造営誌』所収の 仕様書や『皇居御造営内部諸装飾明細図』から知ることができる。こ の竣工時の室内意匠と木工事着手 (明治 18 年 10 月) ${ }^{53)}$ 前後の室内意 匠とを比較すると、当初は伝統的な和風意匠で計画されていたもの が、設計変更によって他の建物には見られない特異な意匠に変更され たことが知られる。本章では、变更前後の室内意匠の特徵を明らかに するとともに、それを前章で明らかにした部屋の用途、すなわち 1 階 は日常政務の場である御座所、2 階は御講学の場としての御学問所で あることと併せて考察し、竣工建物に見られる特異な室内意匠が、部 屋の用途とどのように関係づけられたかについて論じる。

変更前の室内意匠については、明治 18 年 4 月 25 日付の平面図 ${ }^{54)}$ な どから、建物全体が伝統的な和風意匠でまとめられていたことが知ら れる。すなわち、1階の一之間（「御学問所」）は、天井を「二重折上 小組格天井」入側建具を「コシ付きガラスセウジ」、入側小壁を「ツ ノガラマド」、部屋境を「フスマ」、壁仕上げを「ハリ付」とし、2 階 も一之間（「御学問所」）の天井を「格天井板違張」としたほか、基本 的な仕様については、「階下同断二致」55) -と記されている。

竣工した御学問所の室内意匠に見られる特異な意匠としては、まず 框の入隅部分に丸面を取った中国風意匠のガラス障子（図 10） 56) が 挙げられる。木子文庫に収められた建具の計画図から、建具は和風意 匠のガラス障子57) から枠に雷紋を彫った中国風デザイン (図 11) ${ }^{58)}$ のものまで、さまざまに検討されたことが知られる。これらとの比較 から、実施案は枠の形と材質 (桜) ${ }^{59)}$ ・色付け60) によって中国風を表 現したものと見ることができる。同様のデザインは内謁見所の入側建 具にも適用されており、これらは「中段」に建設された内謁見所と御
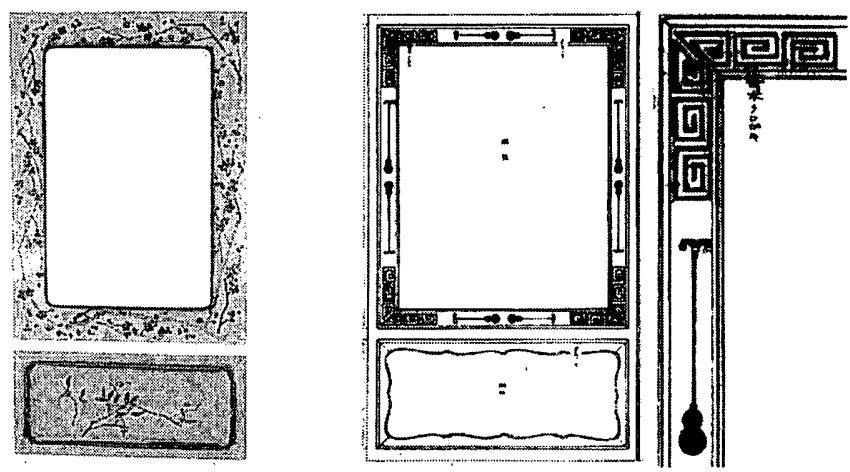

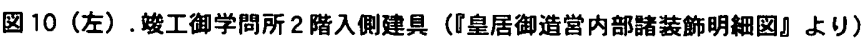
图 11 (右).御学問所建具「絹張陣子」計画案（木子文庫所収・部分）

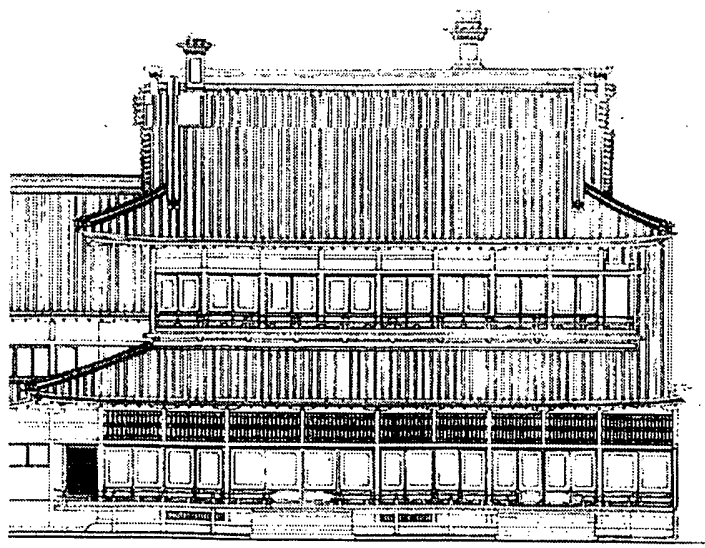

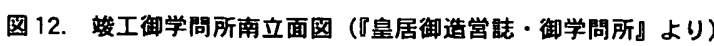

学問所の共通性を示すために、奥宮殿の伝統的な明障子や儀礼空間の 洋風ガラス扉とは異なるデザインを用いたものと考えられる。特に御 学問所では、この建具が入側建具以外にも外周建具や入側小壁のガラ

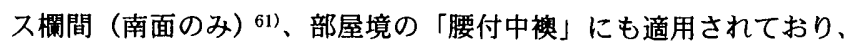
加えて外周建具が表宮殿では唯一、雨戸形式とされたために、この建 具意匠が外観立面に現れ、建物が 2 階建てであることも相まって、竣 工建物の外観を極めて特徵的なものにしている（図 12）。

建具以外では、2 階の天井意匠にも他の建物とは異なる特異な意匠 が用いられた。木工事着手時点では、一之間・広間ともに「格天井板 違張」で計画されていたが、明治 20 年 2 月に作成された「階上御学 問所及廣間北之間橡座敷共格天井及猿頪天井共模様替仕様書」62）で は、一之間の天井が格縁を「黒杮」、格間板を「桐」とした「吹寄格 天井」(図 13 左) に変更され、広間の天井も格縁の材料が「桑」と指 定された。さらに同史料所収の詳細図（図 13右）を見ると、格縁の 黒柿や桑はムク材ではなく、厚さ 3 分〜 4分の板を心材に矧ぎ付けた ものであることが知られ ${ }^{63)}$ 、別の史料 ${ }^{64)}$ では色付けを施すように指 示されている。天井にこうした工芸的な素材や技法65) を用いた例は、 表宮殿の他の建物には見られない。御学問所 2 階のみにこうした比較 的自由な意匠が適用された理由は、ここが表宮殿の中で最も内向きで あり、格式の表現があまり必要とされなかったためと考えられる。

また、室内装飾に用いられた技法やモチーフに注目すると、1 階と 2階ではモチーフが部屋の用途に応じて使い分けられたと考えられる。 表 1 は、竣工建物の 1 階・2階それぞれの一之間に用いられた、天井、 壁張付、入側建具、錺金物、暖炉鏡縁の装飾技法とモチーフをまとめ たものであるが、これを見ると、1 階には折上小組格天井、金砂子蒔 張付、六葉金物といった伝統的な書院造りの意匠が適用されたのに対

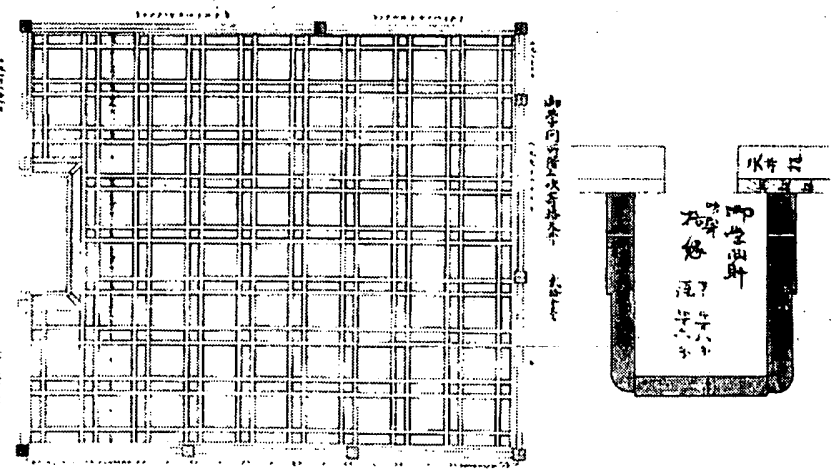

図 13.2 暏「御学問所」の吹寄格天井と格緑の断面（『皇居造営録』所収）

表 1. 御学問所の 1 階 -2 階一の間に用いられた室内意匠の比較

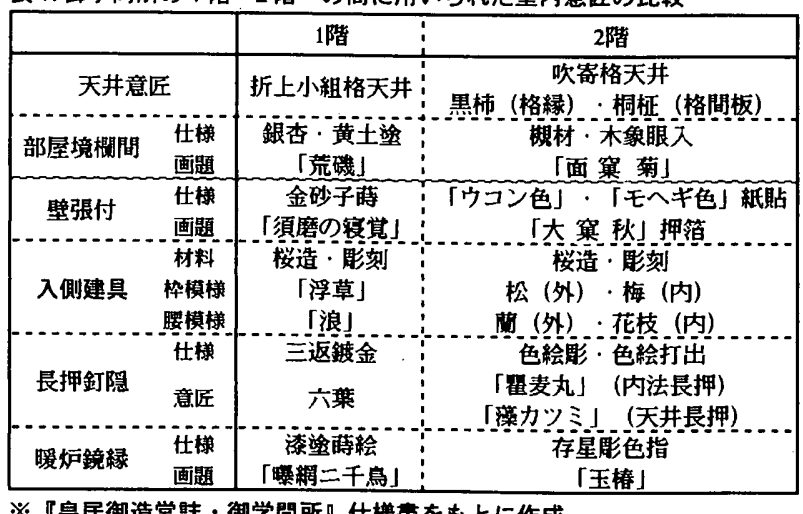

※『皇居御造営誌・御学問所』仕倳書をもとに作成 
し、2 階は吹寄格天井、色紙の張付壁、色絵彫りの錺金物など、全体 的にややくだけた意匠 ・仕様で全体がまとめられた様子が窥える。

装飾モチーフについては、部屋の用途と関係づけて決められた可能 性が高いと見られる。1階の一之間（図14）については、千鳥を描い た「須磨の寝賞」 ${ }^{66)}$ と題する壁張付や腰板・欄間の「浪」・荒磯」な ぞ、和歌に因んだと考えられる画題67) で室内装飾がまとめられたの に対し、2階の一之間（図 15）については、壁張付や欄間の「㑿」 ${ }^{68}$ や「菊」、入側建具の「蘭」や「梅」など、中国風あるいは「四君子 （梅・菊・蘭・竹）」に因んだ画題で室内意匠がまとめられたと考えら れる。1階の和歌に因んだモチーフは、层統的な書院造りの意厎と同 様に、御座所としての「格式」を表現したものと見ることができ、そ れに対して2階の中国風の植物文様や「君子」を象徵するモチーフは、
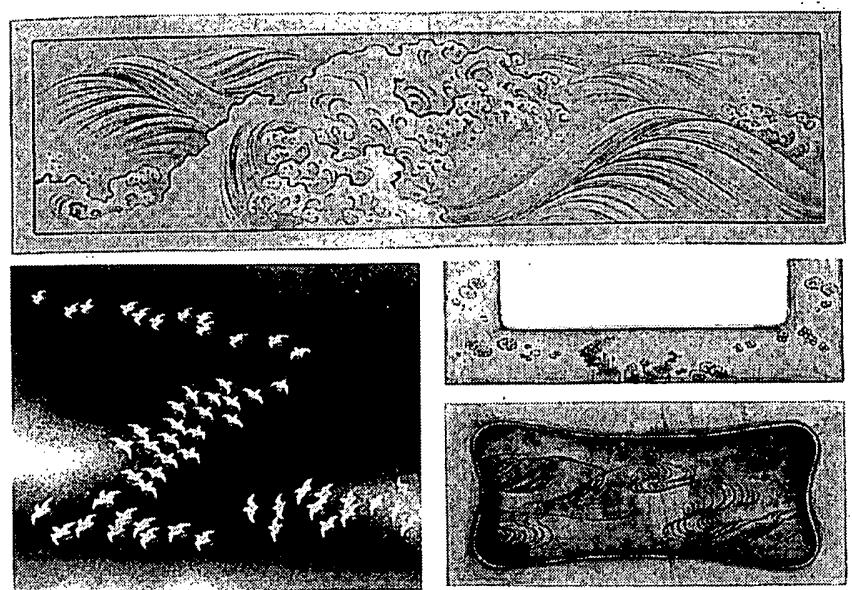

図 14. 1 階「御学問所」の室内意匠（『皇居御造営内部諸装锦明稩図』より）

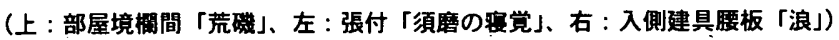

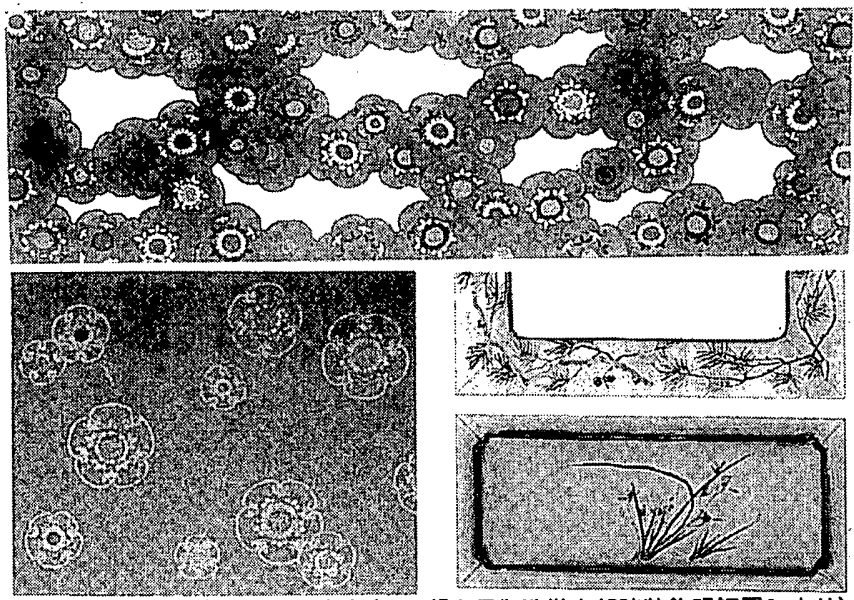

图 15．２階「御学問所」の室内意匠 (『皇居御造営内部諸装飾明細図』より) （上：部屋境欄間「面菓菊」、左：張付「大菓秋」、右：入側建具腰板「闌」）

表 2.「諸宮殿御絵様抜萃」(明治 18 年 9 月頃）記载の張付および杉戸の画題

\begin{tabular}{|c|c|c|}
\hline & 1階 & 2階 \\
\hline $\begin{array}{cc}\text { 建具 } & \text {-之間 } \\
\text { 張付 } & \text { 広間 } \\
& \text { 北之間 }\end{array}$ & 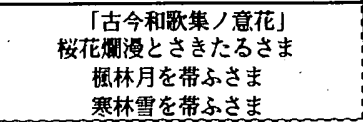 & $\begin{array}{c}\text { 朱喜読書楽四時詩意. } \\
\text { 唐詩ノ意 } \\
\text { 明人詩意 }\end{array}$ \\
\hline $\begin{array}{l}\text { 杉戸画題 } \\
\text { (表/夜) }\end{array}$ & 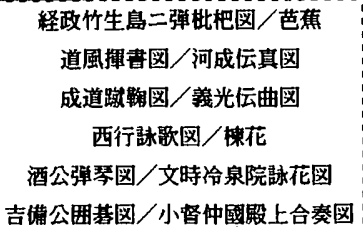 & 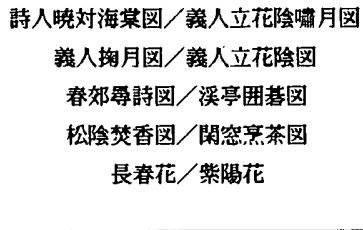 \\
\hline
\end{tabular}

儒教中心の御講学 ${ }^{69)}$ にふさわしい場としての演出を試みたものと理 解できる。そして、同様の装飾モチーフの選び方は、木工事着手前の 明治 18 年 9 月頃に作成 ${ }^{70)}$ された張付壁や杉戸の画題リスト「諸宮殿 絵様抜萃」(表 2) においても見ることができる71)。

以上のように、御学問所の室内意匠に用いられた特異な意匠は、い ずれも1階では日常の御座所、2階では御講学の場という部屋の用途 に因んで決められたものであったと考えられる。本稿の第 2 章では、 赤坂仮皇居の御学問所が洋風重視の御講学内容に因んで洋風意匠で建 設されたことを論じたが、本章で見たように、竣工建物においても御 講学の内容と室内意匠とを関係づける姿勢は見ることができ、また既 往研究では、同様の傾向が近世以前の御学問所と称する建物にも見ら れることが指摘されている72)。よって、赤坂仮皇居も含めた明治期の 御学問所は、御講学の内容が室内意匠に表現されたという点で、近世 以前の御学問所の系譜を継ぐものと理解することができる。

\section{6. 結論}

本稿では、宮内庁や木子文庫所蔵の史料を用いて明治宮殿の「御学 問所」の設計経緯を詳細に検討し、明治期以降に多様化した天皇の日 常的な活動が、建物の平面計画や用途の設定にどのような形で示され たか、またそうした用途が建物の意匠とどのように関係づけられたか に注目して考察を行い、以下のことを明らかにした。

『工事録』所収の赤坂仮皇居に関する改修・増築記録と『明治天皇 紀』に記された天皇の行動を比較したところ、明治 7 年には天皇が日 常政務を執る御座所とは別に、御講学専用の場として洋風の御学問所 が新築され、また御談会や御昼餐など「君臣親和」を図る場として、 御座所の 2 階が 1 室空間に改修された。ここでは天皇の多様な活動の それぞれに対し、個別の場を設けることが重視されたと考えられる。 明治宮殿の造営過程では、吹上宮殿計画以降、御学問所がほほ一貫 して2階建ての建物として計画された。1階と2階の用途については、 1 階はいずれも天皇が日常的に政務を執る御座所として計画され、2 階の用途については、吹上宮殿の「会食所」は御陪食の場として、実 施過程の「御学問所」は御講学の場として計画されたと考えられる。 こうした個々の用途に専用の場を設けようとする姿勢は、明治宮殿と 赤坂仮皇居に共通であり、近代の宮殿としての特徵と理解できる。

一方、なぜ皇居造営計画では仮皇居のように分棟形式でなく、建物 が常に2階建てで計画されたかについては、それぞれの用途に異なる 部屋を与えつつも、「宮殿」を構成する建物としては、あくまで京都 御所と同様に「御学問所」と称する建物 1 棟に緗めることが必要と判 断されたためと考えられ、そこには京都御所をモテルに「宮殿」とし ての格式を表現しようとする姿勢が見られる。こうした京都御所に做 う姿勢が最も顕著に示されたのは、吹上宮殿の計画案であり、そこで は建物の室内や外観に御所風の意匠が多く用いられた。

竣工した御学問所には、他の表宮殿の建物と大きく異なる独特の意 匠が用いられ、特に室内意匠については、1階部分には和歌に因んだ 意匠、2階部分には御講学の中心であった需教に因んだと考えられる 「四君子」などのモチーフが適用された。御講学の場の室内意匠を講 義の内容に因んで決めることは、赤坂仮皇居に新筑された洋風御学問 所にも見ることができ、さらには近世以前の「御学問所」にも見られ る傾向といえる。そのような点において、明治宮殿の御学問所には近 世以前からの御学問所の系譜が継承されていると見ることができる。 


\section{墪}

1）『日本建築学会計画系論文集』第 572 号、pp.159-166、2003 年 10 月

2) 『日本建筑学会計画系論文集』第 578 号、pp.169-176、2004 年 4 月

3）『日本建築学会計画系論文集』第 582 号、pp.161-168、2004年 8 月

4）その他、奥宮殿の建物については「明治宮殿の設計内容に見る『奥宮殿』の 構成と聖上常御殿の建築的特徽」(『日本建築学会計画系諭文集』第 586 号、 pp.163-170、2004年12月掲載予定）にて詳しく論じた。

5）平井論文では、「譏能・平面の雨者共に延宝度に於て対面の為の殿舎として の近世的学問所が成立したと見るべきであろう」（p.604）とされている。

6）藤田論文 (後者) では、中世末から近世初頭にかけての御学問所で行わ扎 た学問・対面が儀礼的でなかった点を重視し、「御学問所が有する私的性格の 不変性」(p.223)や「天皇個人に密着した空間という特質はなお不変だった」 （p.224）として御学問所の性質を位置づけている。

7）宮内庁編『明治天皇紀』（吉川弘文館、1969 年他）全 13 巻

8）『明治天皇紀』明治 7 年 12 月 22 日条

9）宮内庁所蔵「赤坂仮皇居御座敷向之図」（史料番号・218-142、日付なし）

10）註 8 に同じ。「室の広さ約三十帖、絨掞を敷き」とある。

11）『工事録』所収「西洋御学問所御額面掛銅物及下地直三致方共出来費額概 算」(明治 15 年 4 月 17 日) 附図

12) 註 10 参照

13）『工事䟿』所収文書（明治 10 年 11 月 30 日）より。『明治天皇紀』（註 8 に 同じ）には「鉒るに緑色のペンキを以てし」とある。

14）明治 5 年の御請学について、『明治天皇紀』には「時風洋学の行はるっこと 盛なるがため、経書の進講は一時廃せられて專ら和漢の歴史・西洋翻訳書の 類のみ用るらる〉こととなり、弘之は独逸國國法学者ブルンチリーの著を自 ら抄譯して國法汎論と題せる書を進講し、又独逸語の御練習に奉仕す」(明治 5 年 1 月 7 日条) とある。

15）日本公園緑地協会編『日光田母沢御用邸記念公園本邱保存改修工事報告書 (本文編)』(杤木県土木部建築課、2000 年) pp.173-197

16）宮内庁所蔵『赤坂仮皇居切絵図敷物間地六分計』(218-155)。図面内容と 『工事録』所収文書との比較から、明治 8 年 5 月〜 12 月頃の作成之判断した。

17）天保期とされる宮内咱所蔵「赤坂御本殿全備総絵図」(A2-55) を用いた。

18）註 15 の技法調查では、御座所 2 階の部屋境欄間の長押と鴨居が後補であっ ことが確認されている(p.384)。

19）『明治天皇紀』明治 11 年 2 月 13 日条

20）『明治天皇紀』明治 7 年 4 月 30 日条

21）『明治天皇紀』明治 13 年 3 月 17 日条

22）『明治天皇紀』によると、「御講学」は明治 12 年には日曜・祭日、御不例、 暑中休㗇を除くほぼ毎日の約 120 日間行われたが、明治 14 年には合計 17 回 しか行われていない。「御談会」は明治 9 年に 13 回、明治 12 年には 7 回開か れたが、明治 13 年には 3 回以下で、明治 14 年以降は記録されていない。

23）『明治天皇紀』明治 13 年 1 月 24 日条

24）坂本一登『伊藤博文と明治国家形成 一「宮中」の制度化と立憲性の導入-』 (吉川弘文館、1991 年) には、「(筆者註 : 明治 10 年)一一月二七日には御陪 食が毎週金曜日に行われることになり、さらに翌一一年一月一六日には大臣 以外に参議も三日毎輪次に参内祇候することになった。これらはすべで天皇 と内閣とをいっそう密接に結合しようとしたものである。（p.12）とある。

25）木子文庫所收「御学問所及御廁取合共地図・二階繪図」(木094-1-015-1. 2、日付なし)。『下調図』明治 15 年 10 月 4 日案（第 57 号）と一致する。

26）木子文庫所収「御学問所及二階會食所其外共十分一矩計」（木088-2-2、日 付なし)。2階に会食所が設けられており、平面図と同時期と考えられる。

27）木子文庫所収・吹上宮殿御学問所立面図（平：木088-3-001、妻 : 木0883-002、いずれも日付なし)。柱割りが 10 月案の平面図と一致する。

28）木子文庫所収・吹上宮殿屋根伏図（木 108-3-024、日付なし）。『下調図』 所収屋根伏図（明治 15 年 10 月 26 日:第 57 号）と内容が一致する。

29）床板が敷居の高さ（2.6寸）だけ下げて張られている。

30) 絨段の高さが敷居の天端と揃っている。同壁画「能楽御覧」(青山御所) は、

絨段の上に敷居が露出しており、畳を撤去して䄉掞を敷いたように見える。

31）木子文庫所収・吹上宮殿平面図（日付なし、木092-1-008）。『下調図』明 治 15 年 6 月 15 日案（第 48 号）と平面が一致し、「呉服之間」（24 帖）と記 された部屋が付設されている。

32）例えば竣工後の使われ方について、「外國の皇族使節の拝謁等には、式部職 から何國の何々と片假名の勲章の名が迴つて来て、御服掛りの侍従が御学問 所の二階の物置にある桐の箪筒の戔出しから取り出して、私がお内儀に持つ て行つた事もあるが (後略)」(園池公致「明治のお小姓 - 続明治宮殿の思い 出-」『心』第 11 巻 6 号、昭和 33 年 6 月、p.63）との記述が見られる。

33）明治 14 年 11 月 3 日の天長節以降、三大節賜宴は新筑の会食所（約 100 帖） で行われたことが、『明治天皇紀』（明治 14 年 11 月 3 日条）から知られる。

34）『皇居御造営誌・御学問所』の仕様書には、同様の意匠である竣工建物の檙 間について「上下繰板銽形致シ」と記されている。

35）京都御所の御学問所の寸法については、宮内庁京都事務所所蔵の現存建物 の実測図（1962 年作成）記載の寸法を用いた。

36）木子文庫所収・䍿上常御殿平面図（木 109-1-146、明治 15 年 8 月 26 日）

37) 用途ごとに個別の部屋を没けた理由として、部屋ごとに専用の椅子式家具 を常設することが想定されたことも考えられる。赤坂仮皇居における家具の 使用状況には不明な点が多く、本研究ではこの点について論考を控えた。

38）蛙稿「明治宮殿の造営過程に見る木造和風の表向き建物の系譜とその意匠 的特徵」（註 3）第 3 章参照
39）木子文庫所収「地繪図」（木 123-1-028、日付なし）。『下調図』明治 16年 10 月 10 日案 (第 76 号) と内容が一致する。

40）木子文庫所収・後席ノ間平面図（木123-2-087、日付なし、明治 16 年 10 月頃）は、「休敗之間」と同じ位置に 2 階建てで計画された。

41）『明治天皇紀』明治 22 年 3 月 26 日条、同年 6 月 25 日条など多数。

42）木子文庫所収「御学問所矩計」（木 094-1-011、日付なし）。平屋建て。 43）木子文庫所収・内謁見所・御学問所起こし絵図 (木106-1-001、日付なし) 44)「是ヨリ先キ一月二十二日山里二於二御造営模型天覧ノ際御学問所へ二階筑

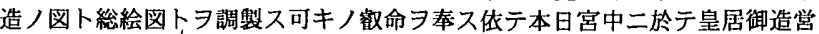
図习天覧二供ス」(『皇居御造営誌・巻之六』明治 17 年 2 月 4 日条) とある。 45) 『皇居御造営誌・巻之七」明治 18 年 10 月 7 日条

46）木子文庫所収・御学問所他屋根伏図（木100-2-041、明治 17年 2月 14日） 47) 『皇居造営録・御学問所』所収・御学問所平面図 (明治 17 年 5 月 7 日)

48）木子文庫所収「御学問所地之間図・御二階」（木094-1-033-1・2、明治 18 年 1 月 28 日)

49）日露戦争宣戦布告に関する御前会議（明治 37 年 2 月 4 日）では、2室が一 体的に使用されたことが、聖徳記念絵画館壁画「対露宣戦布告御前会議」お よび宮内庁所藏『宮中御前会議布設皇族会議枢密院議場布設略図』所収「表 御座所二於テ御前會議之節御布設略図」(明治 37 年 2 月 4 日) から知られる。

50）木子文庫所収「御学問所二階建拾分壹矩計」(木 094-2-010、日付なし)。 2 階部分に「二拾帖之間天井高サ」との書き込みが見られる。

51）木子文庫所収「御学問所二階建矩計」(木107-1-023、明治 18 年 9 月 13 日) 52）2階「御学問所」は、拨工後に「御二階一之間」へと改称された。また園 池公致「明治宮殿の思い出」(『世界』 129 号、昭和 31 年 9 月) には「階下と ほとんど同じ間取りだが、これは全く使用せられなかつた」(p.181) とあり、 竣工建物の 2 階は明治期にはほとんど使用されなかったと考えられる。

53)『皇居御造営誌・巻之七』明治 18 年 10 月 7 日条

54）木子文庫所収「御学問所地之間図」（木 094-1-035-1・2、明治 18 年 4 月 25 日、明治 18 年 6 月 7 日更正)

55）例えば「仕法書」(先揭)には、「二階惣拭板張床力同断二致シ其外數居眗 居差鴨居長押廻リ共仕様前同断」「御学問所御床つ階下同断二致シ〉とある。

56)『皇居造営録・御学問所』所収「御学問所及呉服之間共建具管造製作仕様書」 (明治 20 年 5 月）から、建具意匠の決定が明治 20 年 5 月であることがわかる。 57）木子文庫所収・建具詳細図（木 092-4-010、明治 19 年 2 月 28 日）

58) 木子文庫所収「御学問所及廣間北之間絹張障子拾分一之図」(木093-2-08203、日付なし)。他に中国風の計画案としては、木子文庫所収「御学問所二階 外側外面舞良戸硝子障子拾分一之図」(木093-2-082-01、日付なし) がある。 59）中村圭介『文明開化と明治の住まい-暮らしとインテリアの近代史 (上)-』 （理工学社、2000 年）に、下明治後期には中産階級にも広がり、代用材のサク ラやケヤキを着色し、唐木にみせる手法が発達した」（p.141）とある。

60)『皇居造営録・御学問所』所収「御学問所桜造建具水木賊磨キ着色共受負申 込之義伺」（明治 21 年 6 月 1 日）には、「着色用木炭」と記されている。

61）『皇居造営録・御学問所』所収「御学問所階上廣間欗間仕㹉ノ費仕增受負申 付何」(明治 20 年 6 月 18 日) 附図

62)『皇居造営録・御学問所』所収「階上御学問所及廣間北之間椽座敷共格天井 及猿頪天井共模様替仕様書」(明治 20 年 2 月)

63）註 62 附図「御学問所格天井縁知木正寸之図」(明治 20 年 2 月)、「格縁知付 方之図」を見ると、知付けは「千切」を使って行うよう指示されている。

64)『皇居造営録・御学問所』所収「御学問所階上同一之間廣間共格天井縁色付 仕様書」（明治 20 年 7 月）には、黒柿について「右仕様油煙二晒蜕 $习$ 加へ解 キ致シ刷毛引色付之事」と記されており、桑については「右仕様ヤシヤロー ハロクド石灰回調合致シ右共ロシ汁石灰习加へ」(日は不明)とある。

65）農商務省山林局編『木材八工芸的活用』(大日本山林会より明治 45 年発行 ・ 昭和 57 年財団法人林業科学技術振興所より復刻) を見ると、「各論第三 : 建 築用材」（p.187）では床柱の材料としてのみ紹介されているのに対し、「各 論第四：指物用材」では、桑の色付けを石灰水で行うこと、黒柿が狂い安く 精巧な仕事が必要であることなどが記されている（pp.271-272）。

66）『皇居御造営内部諸装飾明細図』に「須磨の寝党」と記されている。

67) 例えば、源兼鸟「淡路島かよふ千鳥の鳴く声に幾夜瞢覚めぬ須磨の関守」な どが考えられる。

68）『広辞苑』(第二版補訂版、岩波書店、1978 年)には、「鳥の巣の卵を包 含する形状を表現した漢民族使用の模様」(p.343) とある。

69）『明治天皇紀』によると、元田永学による論語の進講は明治 5 年以降廃止さ れていたが、明治 11 年 1 月に再開され、天皇も「漸次経学を好ませらる〉に 至る」（明治 11 年 1 月 7 日条）ようになったと記されている。

70)・皇居造営録・絵画』所収。明治 18 年 9 月付けの史料と内容が一致する。

71 ) 明治 18 年 6 月 11 日以前の画題を写した「眰居御坐敷絵様」(『皇居造営録・ 絵画』所収）には、画題を $1 \cdot 2$ 階で区別する姿勢があまり見られない。

72）斎藤英俊「山里と草庵」(日本美術全集 14 『城と茶室』、講談社、1992 年) では近世の学問所の意匠について、「草庵的意沂が学問に結びついて近世まで 引き継がれている」(p.177) と、学問の内容と建物の意匠に関係が見られる ことを指摘しており、同論文が参照した山崎浩章「近世上層住宅における学 問所の形態と用法について」(東京工業大学建築学科提出修士論文、1986 年 3月）では、上層公家住宅の学問所に適用された草㢆風意匠が、東山院御所以 外の御所には適用されなかったとある。明治宮殿において、御講学内容と意 匠との関係は 2 階御学問所の装飾モチーフに見ることができ、御所にくだけ た意匠を用いないという点は、1階の御座所に格式重䘽の書院造風意匠を適用 し、内向きの 2 階に比較的自由な意匠を用いた点に窥える。 